\title{
A Critical Review of the Literature on Firm-Level Theories on Ship Investment
}

\author{
Sinem Celik Girgin * (1), Thanasis Karlis ${ }^{(1)}$ and Hong-Oanh Nguyen \\ Department of Maritime and Logistics Management, Australian Maritime College, University of Tasmania, \\ Newnham 7248, Australia; thanassiskarlis@gmail.com (T.K.); O.Nguyen@utas.edu.au (H.-O.N.) \\ * Correspondence: sinem.celikgirgin@utas.edu.au, Tel. +61-045-066-5916
}

Received: 28 November 2017; Accepted: 17 January 2018; Published: 19 January 2018

\begin{abstract}
The maritime industry is one of those rare industries that are both highly international integrated to international trade and also highly capital intensive dependent on substantial investment amount. In the literature, ship investments have not been widely examined through the firm-level investment theories to explore the link between investment level and asset price valuation. The general trend in the literature of ship investments is to analyse the relationship among the shipping markets (newbuilding, second-hand, freight rate and scrap) and their impact on asset price valuation, the timing of investments and market entry and exit conditions. In this paper, we extensively reviewed the literature of firm-level investment theories and ship investments. We showed that the application of firm-level investment theories to the ship investments is confined to the basic investment valuation models, such as Net Present Value and Real Option Analysis. Ship investments need to be examined by firm-level investment theories to define firm/industry value maximization level within the approach of the solid investment theories.
\end{abstract}

Keywords: investment theories; microeconomics; ship investments; maritime industry

JEL Classification: G11; G3; L2; O12

\section{Introduction}

Business investments in the fixed capital have a crucial role in a nation's industrial and economic growth. Nowadays, the world average of the gross fixed capital formation corresponds to about 20 percent of Gross Domestic Product (GDP). ${ }^{1}$ Its contribution to the economy is not confined to the GDP. Investments facilitate the growth of factors of production both in physical and human capital stocks (Barro and Martin 2004; Uzawa 1965). Furthermore, the relationship between investment and factors of production is assumed to be bidirectional. As the firm continues to invest, the returns increase since new knowledge and technology are discovered (Arrow 1962). The motivation behind the investment and therefore its contribution to the nation's economy is closely linked to the growth of international trade which gives the opportunity to maximise the wealth of a nation by discovering or opening up new markets. The fact that $90 \%$ of the world's trade is carried by sea puts the maritime industry in a critical role as a bridge to the markets of the international trade (UNCTAD 2016). The link between maritime industry and the economy has been emphasised by researchers (Harlaftis and Kostelenos 2012; Kang et al. 2016), and Cheng (1979) notes that the maritime transportation can be seen as a phase of production which is indispensable to economic progress.

The shipping industry as being a vital chain of economy and trade, the economic structure of the industry has also received increasing attention in the literature. The economics of shipping transport

1 The World Bank website visited online at 09/10/17 https:/ / data.worldbank.org/indicator/NE.GDI.FTOT.ZS. 
have been studied by various scholars (Buckley 2008; Karakitsos and Varnavides 2014; Metaxas 1971; Stopford 2009; Talley 2011; Zannetos 1966), and they have contributed to the literature by exploring the economics of shipping markets (newbuilding, second-hand, freight and scrap markets), freight fluctuations and the interrelationship between the markets. Mostly, ship investments have been studied through the market analysis perspective rather than through the application of firm-level investment theories. While there are numerous sources on the macroeconomics of the maritime industry, on the microeconomic level and in particular, on the firm-level investment approach, the literature is very scarce. The empirical research to explain the investment decision in the new or second-hand ships by existing ship owners or new entrants is rare and sporadic. From that perspective, there is an empty field in the literature to be filled regarding the interpretation of investors' decision on ships whether new or second-hand and ship price valuation in the market with the application of firm-level investment theories. Ship investments in the literature started receiving increasing attention by researchers from the 1950s as a consequence of data availability and the role of shipping during globalisation. This inference brings the question which as to why the shipping industry has been absent from mainstream research in economics and economic history, despite having a very long and fascinating contribution in the world history (Paine 2014). The absence of shipping industry from mainstream research is vividly noted by Harlaftis et al. (2012) that note that it is common to neglect the service sector in economic and historical research. Studies of the emergence of modern economic growth in industrialised economies usually focus on manufacturing, while seldom emphasising the importance of the service sector activities. Additionally, the maritime industry has been absent from mainstream research due to its inherent international character, which blurs the links to individual economies. The product of shipping, sea transport, takes place beyond national boundaries, and its income is earned abroad, removed from the economic structures of a specific country. It is indicative that economists analysing national economies have classified shipping income as "invisible earnings". The third reason for the invisibility of the business of shipping is that it is "intangible", and its absence from the core of economic analysis mirrors the situation of many other service industries. Finally, even the participants in the industry would like to remain "invisible". Indeed, some of the most prominent ship owners created elaborate organisational structures with the aim to obscure questions of asset ownership and strategies.

In the literature, there are five mainstream firm-level investment theories: accelerator, expected profit, liquidity, neoclassical and $\mathrm{Q}$ theory of investment, which apply to the shipping industry. The firm-level investment theories seem to have stagnated after the last quarter of 20th century. ${ }^{2}$ In particular, investment theories between the 1900s and 1970s have taken a substantial role in the literature and showed significant progress. However, after the 1970s, the development of new investment theories has slowed down, and most of the subsequent studies dealt with the introduction of a new approach to existing theories, rather than suggesting a different theoretical approach. Some economists, such as Chang (2014) and McCloskey $(2002,2006)$, argue that the innovative growth process of economic thought slowed down in the 21st century.

The review of the five major firm-level investment theories, provided in the following section, highlights that most of the investment theories deal with determinants of investments under the assumptions of either instantaneous adjustment or distributed lag structure which is not related to any optimisation process. The $Q$ model seems to be the only exception which contains a theoretical foundation to allow a study of investment determinants by the principles of the economic relationships.

This paper provides a critical review of the five main firm-level investment theories and the literature on ship investments. Notably, the literature on ship investments has focused on the review

2 Besides five major firm level investment theories, time series investment model derived by Kopcke (2001) where the model considers the trends and cycles evident in recent experience which are sufficiently stable to describe the course of the investment in the future. The model is formulated by as $I_{t}=\sum_{i=1}^{n} a_{i} I_{t-1}+\sum_{i=0}^{n} b_{i} Q_{t-1}, I$ is investment, $Q$ is output. However, the model has not been widely applied by other scholars. 
of the ship investment decision making with a particular focus on the choice between new and second-hand ships and ship price valuation. The primary aim of this paper is to find a research gap and to justify a new type of method to be used to assess ship investment. Considering the aim of this paper, the main features of the five mainstream firm-level investment theories and the ship investment literature are reviewed to discuss the applicability of the firm-level investment theories in the shipping investment decision process. Based on the aim of this paper, following research questions are to be answered in this paper:

1. What are the central assumptions of firm-level investment theories that can affect the application in the shipping industry?

2. Which are the most commonly used methods to research ship investments in the bulk and container shipping?

The rest of the paper is organised as follows. Section 2 introduces the ownership structure in the container and bulk shipping markets and provides an overview of ship investment in the world. Section 3 presents the theoretical approach of the five main firm-level investment theories over the period of the 1910s to 1980s. Section 4 elaborates the empirical studies in ship investments under two main categories, Bulk Shipping and Container Shipping after a systematic review of the literature from the 1960s until now. Finally, Section 5 reviews the gap in the literature and provide suggestions for the future research.

\section{Overview of Ship Investments}

The bulk and container shipping markets show a different pattern of ownership and therefore investors. The ownership in the container market in terms of container ship capacity includes owned ships by the liner companies and chartered in tonnage from independent ship managers not engaged in the provision of liner services (UNCTAD 2017). The market structure in liner shipping resembles an oligopolistic market structure. Moreover, after the recent mega container-shipping mergers and acquisitions, the degree of market concentration has increased. UNCTAD (2017) reported that as of January 2017, the top 17 carriers collectively controlled 81.2 percent of the global liner capacity, while a year earlier the 20 leading carriers controlled 83.7 percent of the global liner capacity.

In the bulk shipping markets, and particularly the tanker market, the ownership structure has significantly changed after the 1950s. While oil companies in the 1950s controlled the majority of tanker ships, in 2000s, the majority of the tanker fleet is controlled by independent owners and a significant percentage of the fleet operates in the spot market (Glen and Christy 2010; Veenstra and Fosse 2006). In the dry bulk market, following the dispersion of state-owned fleets after the collapse of the former Soviet bloc, independent ownership has increased, and the spot charter market has always been a significant percentage.

In the literature, there are some studies on containership investments (Fan and Luo 2013; Fan and Yin 2015; Luo et al. 2009) from either firm level or industry level perspective due to firm-level data availability for container shipping companies. However, the studies in bulk shipping are confronted with low availability of firm-level data. Therefore, industry-level data is mostly used in studies on the bulk shipping (Alizadeh and Nomikos 2007; Merikas et al. 2008; Tsolakis et al. 2003). Depending on data availability, firm-level investment theories can be applied on industry level in bulk shipping and on firm and industry level in container shipping.

In the context of ship supply growth, in long-term, the shipping industry receives the increasing attention from investors along with the growing world trade. However, it shows a highly volatile trend in the short run due to the effect of external economic shocks and regional disputes. According to UNCTAD (2017), the order book of the dry bulk sector has reached a peak level and increased from 75 million dead-weight tons (dwt) in 2007 to 322 million dwt in 2011. Similar peak levels are recorded in the oil tanker sector during 2006 and 2009 with an increase from 97 million dwt to 192 million dwt. The bulk shipping, both dry and wet bulk, have witnessed a sharp decrease as a consequence 
of the Global Financial Crisis, 2008 (GFC). However, the order book of container shipping has been less affected from GFC and reached a peak level of 79 million dwt, in 2008. In 2016, the order book of container ships reached 43 million dwt. In addition, to the slowdown in the order book, demolition activities have increased recently. In 2016, the shipbuilding activity contracted by 1.7 percent, while ship scrapping increased by 25.7 percent (UNCTAD 2017). The recovery process in the ship investments has not shown a substantial increase after GFC which is, in fact, an expected outcome since global economic growth is still in the recovery process. The World Economic Outlook Report of IMF (2017) reported that the global growth rate is still far below the expectations and the recovery has not been completed yet. While the global economic activities showed an upswing move in 2017 and there are definite expectations for 2018, growth remains weak in many countries, and inflation is below target in most advanced economies.

\section{Firm-Level Investment Theories}

The fundamentals of the firm-level investment theory go back to Keynes (1936) and Fisher (1930). They both argued that investments are made until the present value of expected future revenues is equal to the opportunity cost of capital. Fisher (1930) primarily conceptualised the central concept of neoclassical investment theory which is the maximisation of the present value of the firm, introduced the equation of Net Present Value (NPV) in the book of "The Rate of Interest". The investment is expected to produce future cash flows, $C(t)$ and the net present value can then be written as:

$$
N P V=\sum_{t=1}^{T} \frac{C_{t}}{(1+r)^{t}}-C_{0}
$$

where, $C_{t}$ is net cash inflow during the period $t, C_{0}$ is total initial investment costs and $r$ is the opportunity cost of capital (discount rate).

As long as the expected return on investment, abbreviated as $i$, is above the opportunity cost of capital (discount rate), $r$, then the investment will be worthwhile. In case of the cost of opportunity cost is equal to the expected return on investment, then $N P V$ will be equal to zero. The expected return on investment, $i$, is equivalent to Keynes' marginal efficiency of capital and Fisher's internal rate of return.

$N P V$ and Discounted Cash Flow (DCF) are well known and widely applied analysing tools in investment decision-making process of the firms. A project can be accepted when the value of the $N P V$ is greater than or equal to 0 . However, the $D C F$ is a static tool of analysis and ignores future uncertainty likely to occur that can negatively affect future cash flows. This implies that the $D C F$ analysis does not comply with real-world dynamic interactions and the highly risky and uncertain investment environment of the shipping industry asks to consider an alternative method to evaluate investment alternatives.

As a alternative to the static DCF method, the dynamic Real Option Analysis (ROA) method was introduced by Dixit and Pindyck (1994) and is widely applied in the shipping industry (Bendall and Stent 2005; Bendall and Stent 2007; Dikos 2008; Dikos and Marcus 2003; Dixit and Pindyck 1994; Gkochari 2015). The ROA is treated as an alternative method to manage capital budgeting process under uncertainty and irreversibility with additional options which can be exchanged with low-risk income streams associated with one strategy with that of another strategy (Bendall and Stent 2007). More recently, Balliauw (2017) applied ROA in container shipping to analyse the performance in the shipping markets of a theoretically developed model to market entry and exit decision of ship owners. The author found that the theoretical model, $R O A$, conforms to the real market values when the market is steady. However, in case of fluctuations of in sale and purchase prices, then the model needs to be realigned by new market values.

Following the basics of investment evaluation tools, we will now focus on the accelerator theory which is the oldest of the firm-level investment theories. This will be followed by the profit theory, the liquidity theory, the neoclassical theory and the $Q$ theory. 


\subsection{Accelerator Theory}

The simple accelerator theory was introduced by Clark (1917) and in the simple accelerator model, the actual capital stock $K_{t}$ adjusts instantaneously to the desired capital stock, which is formulated as $K_{t}=K_{t}^{*}$. Refer to principles of accelerator theory of investment behaviour; the desired capital is proportional to the output which is constant, $\mu$ :

$$
K_{t}^{*}=\mu Y_{t}
$$

The equation follows that net investment, $I_{n t}$ which is the increase in the actual capital stock can be specified as:

$$
I_{n t}=K_{t}-K_{t-1}=K_{t}^{*}-K_{t-1}^{*}=\mu\left(Y_{t}-Y_{t-1}\right)
$$

Equation (3) demonstrates the link between investment and changes in output, which expresses that change in output might lead to an accelerated change in investment. The model assumes that a complete and instantaneous adjustment of the capital stock. As being the earliest model, the accelerator theory was exposed to many criticisms by scholars (Chenery 1952; Koyck 1954; Tinbergen 1938) who developed the flexible accelerator model. The first criticism was that the model was restricted by the unrealistic assumption of instantaneous adjustment of the capital stock. The second, as econometric results show that the estimated value of the parameter $\mu$ is much smaller than the observed ratio of capital stock to output. The third criticism was that in the simple accelerator model, the prices of capital equipment, wages, taxes and interest rates were ignored (Baddeley 2002). In response to the drawbacks of accelerator model, the flexible accelerator model was formulated by Goodwin (1948) and Chenery (1952). In particular, Chenery (1952) added reaction lags in the capital stock. These lags show the time gap between changes in demand and new investment activity. These lags are able to capture the delays between the investment decision and the investment expenditures. The actual level of capital in period $t$ was denoted by $K_{t}$ and the desired level by $K_{t}^{*}$, capital is adjusted toward its desired level by a certain proportion of the discrepancy between desired and actual capital in each period, which is formulated as follows:

$$
K_{t}-K_{t-1}=\lambda\left(K_{t}^{*}-K_{t-1}\right)
$$

where $0<\lambda<1$ is a parameter, this equation is from Koyck (1954) distribution lag function.

To obtain investment function, investment variable inserted into the Equation (4) which states that changes in the stock capital level equal gross investment less depreciation:

$$
I_{t}=\lambda\left(K_{t}^{*}-K_{t-1}\right)+\delta K_{t-1}
$$

where $I_{t}$ is gross investment, and $\delta$ is the depreciation rate.

The main difference between simple accelerator model and flexible accelerator model is flexible accelerator includes in lags in capital stock which avoids the unrealistic assumption of instantaneous adjustment of the capital stock and corresponds to the dynamic structure of investment.

\subsection{Expected Profit Theory}

The expected profit theory emerged as a subsidiary hypothesis under the accelerator theory (Tsiang 1951). Significant contributions to profit theory were made by Tinbergen (1939), Kalecki (1949), Klein (1951) and Grunfeld (1960). The expected profit model was developed based on the approach is that the investment decisions are made by considering the present value of expected future profits (Kuh 1963). Tinbergen (1939) has clarified the concept of profit theory as: "There is fairly good evidence that the fluctuations in investment activity are in the main determined by the fluctuations in profits earned in the industry as a whole some months earlier" (Tinbergen 1939). However, the expected profit model was later criticised by Grunfeld (1960) by adding the current profit into the flexible accelerator model and 
found that the partial correlation between profits and investment was insignificant. In the aftermath, the author states that the results did not confirm that profits are a good measure of expected profits or that they tend to lead investment expenditures. He added that; "The observed simple correlation between investment and profits seems to be due to the fact that profits are just another measure of the capital stock of the firm and one that is in most cases inferior to the measure that we have constructed." (Grunfeld 1960). In Grunfeld (1960)'s theory, desired capital is proportional to the market value of the firm in the securities market.

$$
K_{t}^{*}=\alpha_{1}+\alpha_{2} V_{t}
$$

where $V_{t}$ is the firm's market value, $\alpha_{1}$ and $\alpha_{2}$ are parameters. Combining Equation (5) into the distribution lag function (4), then following equation produced:

$$
I_{t}=\beta_{1}+\beta_{2} V_{t}+\beta_{3} K_{t-1}
$$

The expected profit model has some advantages and disadvantages to apply in business models. The main advantages of the theory is that which recognises the role of expected profit in the investment decision. Besides, the market value of the firm was measured as the market value of stocks outstanding plus the book value of debt including short-term liabilities. The expected profit theory is the first model used the market value of the firm in analysing the investment behaviour which inspired to create $Q$ theory.

\subsection{Cash Flow/Liquidity Theory}

The liquidity theory was developed as an alternative to the criticism of the accelerator investment theory and the expected profit model. The theory was proposed by Meyer and Kuh (1957), Anderson (1964), Kuh (1963), Meyer and Glauber (1964) and Duesenberry (1958). The main argument of the liquidity theory is that cash flow dominates the level of investment and when internal funds are exhausted, the schedule of the supply funds rises sharply to keep the capital level at the desired point (Jorgenson and Siebert 1968). In the liquidity theory of investment behaviour, desired capital is proportional to liquidity,

$$
K_{t}^{*}=\alpha L_{t}
$$

where $\alpha$ is the desired ratio of capital to the flow of internal funds available for investment.

In order to obtain the investment function, $V_{t}$ in Equation (7), expected profit model, can be replaced by $F C_{t}$, then produced Equation (9):

$$
I_{t}=\beta_{1}+\beta_{2} F C_{t}+\beta_{3} K_{t-1}
$$

The cash flow-liquidity model reflects both the firm's internal funds and the profit levels (Kuh 1963). Therefore, it is not an alternative to the expected profit model. Rather it might be seen as augmenting the expected profit model by incorporating the cost of investment funds. However, the main drawbacks of the liquidity model are related to constraints not taken under consideration such as transaction costs in the financial markets and the fact that factors such as the interest rates and the prices of equipment and machinery are ignored.

\subsection{Neoclassical Theory}

The neoclassical theory of investment theory is based on optimal capital accumulation (Jorgenson and Siebert 1968) which is extensively studied by Jorgenson (1963, 1967, 1971). The investment theory is founded on the assumption that capital accumulation is based on the objective of maximising the utility of a stream of consumption. The main principle of the theory of optimal capital accumulation meets the basic objective when: "The firm maximizes the utility of a consumption stream subject to a production function relating the flow of output to flows of labor and capital 
services." as Jorgenson (1967) stated. The net investment is equal to total investment less replacement. There is a connection between the capital stock $K(t)$ and the rate of investment $I(t)$ which takes the form as:

$$
\dot{K}(t)=I(t)-\delta K(t)
$$

The Equation (10) states that the rate of change of the capital stock, $K(t)$, is equal to the purchase of new capital, $I(t)$, less the amount of capital depreciation, $\delta K(t)$. The investment function with lag distribution suggested by Jorgenson $(1963,1967)$, given in Equation (11):

$$
I_{t}=w_{0}\left(K_{t}^{*}-K_{t-1}^{*}\right)+w_{1}\left(K_{t-1}^{*}-K_{t-2}^{*}\right)-\alpha_{1}\left(I_{t-1}-\delta K_{t-2}\right)+\delta K_{t-1}
$$

Compared to previous models, the neoclassical model has some advantages. First, the net worth maximisation model defines the link between investment and expected profits of firms. Second, the neoclassical theory of investment primarily identified the user cost of capital, which was not considered in previous models. Additionally, the user cost of capital concepts has inspired the $Q$ model to include adjustment cost function. Lastly, the neoclassical model consists of many other variables such as tax, interest rate, output level; therefore it is easier to measure their impact on investment. However, the model is subject to criticisms. First, output has still a substantial effect as a determinant of investment, compared to the user cost of capital which has a modest effect on investment function (Chirinko 1993). Second, the investment decision process is considered as dynamic instead of being static (Kuh 1963), and the Jorgenson (1971) attempted to modify the neoclassical model subject to dynamic optimisation. However, the first order conditions used to derive the optimal level of capital stock stayed static.

\subsection{Tobin-Q Theory}

The $Q$ theory of investment has been developed by Brainard and Tobin $(1968)$ and Tobin $(1969,1978)$, but the foundation of the model goes back Keynes (1936), he stated that: "Daily revaluations of the Stock Exchange inevitably exert a decisive influence on the rate of current investment. For there is no sense in building up a new enterprise at a cost greater than that at which a similar existing enterprise can be purchased; whilst there is an inducement to spend on a new project what may seem an extravagant sum, if it can be floated off on the Stock Exchange at an immediate profit." (Keynes 1936). The model proposed that investment expenditures are positively related to average $Q$, which has defined as the ratio of the financial value of the firm to the replacement cost of its existing capital stock (Chirinko 1993).

In particular, $Q$ model emerged to address two fundamental problems of neoclassical theory and accelerator theory of investment. The first problem was the capital adjustment process which was initially accepted as instantaneous and complete in each period, in the neoclassical model and $Q$ model, the adjustment cost is described as a strictly convex function. The convex adjustment cost was initially proposed by Jorgenson (1963), Eisner and Strotz (1963), Lucas (1967) and Gould (1968), which was incorporating the adjustment cost function into firm value maximisation function of the neoclassical model. The second problem was that the role of expectations in future investment opportunities was not evaluated by the previous studies and Brainard and Tobin (1968) and Tobin (1969) worked on this problem. They suggested that investment is made until the market value of assets is equal to the replacement cost of assets (Eklund 2010). Then the investment Equation (6) introduced as below:

$$
\left(\frac{I}{K}\right)_{t}=\beta\left[Q_{t}-1\right]+u_{t}
$$

where $\beta=1 / \alpha, u_{t}$ is an error term, and $Q$ is called "marginal $Q$ ", which equals the ratio of the shadow price to the replacement unit cost of capital. The $Q$ value captures the effect of an additional dollar of capital on present value of profits, therefore, the firm decides to increase the capital stock if $Q$ is high and reduce the capital stock if $Q$ is low (Romer 2006).

The marginal $Q$ variable is unobservable, and therefore its data is not available. To solve it, Tobin (1969) replaces the marginal $Q$ variable with the average $Q$, which is the ratio of the firm's market 
value to its replacement cost. Use of average $Q$ in place of marginal $Q$, since investment regression is likely to suffer from misspecification. Hayashi (1982) worked on this problem and stated that marginal $Q$ and average $Q$ is identically equal, $q_{m}=Q_{a}=1$, if the firm is a price taker (perfect competition), and their production and installation functions are linear homogeneous. If this condition is violated, then investment equation is likely to be biased.

Application of $Q$ model to various industries has risen a question as to how to calculate $Q$ variable in practice. There are some different calculation methods offered by various scholars based on the specific research field where $Q$ ratio has been used. Peters and Taylor (2017) worked on intangible capital and investment and computed the $Q$ variable as the ratio of the total investment includes the investment in physical and intangible capital to the total capital stock includes physical and intangible capital stocks. Furthermore, Hall (2001) defined the $Q$ variable as the ratio of the value of ownership claims on the firm, less the book value of inventories, to the replacement cost of equipment and structure.

The role of $Q$ theory was widely questioned by scholars, and its explanatory power in investment relation was accepted poor (Bond and Van Reenen 2007; Caballero et al. 1995). However, more recently Kilponen and Verona (2016) studied on the $Q$ theory of investment by the frequency domain on the U.S. data of corporate fixed private non-residential investment in equipment and structures from 1972 to 2007. They reinterpreted $Q$ theory based on Rua (2011) study, a wavelet approach to forecasting. In contrast to the literature, they found that $Q$ model might be better explaining short-term relations rather than long-term ones by considering frequency relationship between $Q$ and investment. Moreover, they found that using the wavelet approach and the proxies for $Q$ significantly increases the predictive power of the investment equation. In some research, extended $Q$ model of investment decision is integrated into dynamic risk management analysis with financial tools. These showed that for the firm's investment opportunities and when there are no fixed costs of investment the marginal $Q$ is a more accurate measure than average $Q$ (Bolton et al. 2011). Moreover, $Q$ ratio, itself, applied to measure the performance of the airline industry ( $\mathrm{Li}$ et al. 2004) and proved that $Q$ ratio captures additional dimensions of the airline performances compared to other financial measures. More recently, Skjeggedal (2012) applied $Q$ theory into Norwegian housing from 1992 to 2011, where the value of Norwegian housing, $Q$, is defined as the ratio of housing prices to the construction costs of new housing and housing is defined as the aggregate housing stock in Norway's national accounts. The author stated that the value of housing is significantly related to housing investment according to the $Q$ theory model of housing.

\section{Empirical Research in Ship Investments}

The shipping industry is usually categorised under four markets: the newbuilding market, the freight market, the sale and purchase market, and the demolition market (Stopford 2009) and each market is further broken down according to the principal vessel types: Dry and Wet Bulk, Container, General Cargo and others. The literature on ship investments has mostly examined two primary markets, newbuilding and second-hand markets, which are very intensive and active investment markets (Tsolakis et al. 2003); and their interactions with freight markets. In this paper, the empirical studies on ship investments have been reviewed within this perspective (newbuilding, second-hand and freight markets relationship) and they are mainly grouped under two main sectors: Bulk and Container Shipping Markets.

\subsection{Bulk Shipping Market}

\subsubsection{Dry Bulk Shipping Market}

The recent empirical studies in the bulk or container sectors mostly focused on specific vessel types; they tend to avoid generalising the research outcomes on the vessels types since they have structural differences. However, some early researchers examined country level investments for all 
vessel types, except some well-known studies, such as Zannetos (1966) that worked on tankers and Metaxas (1971) that worked on the economics of tramp shipping. However, Marlow (1991c) had an empirical study followed by the research series (Marlow 1991a, 1991b) to analyse the maritime industry regarding the relationship between industry incentives and investment levels for UK shipping industry. In the research series, besides providing strong theoretical background for the shipping industry incentives and investment level, the empirical model has been tested by a number of modified variables to obtain the best output. The model did not produce the expected outcome of a positive link between incentives and investment levels. This unexpected result may be due to running the analysis for all type of vessels which is likely to lead bias in the sample, and further data collection might be required to determine precisely how incentives affect investment levels.

The studies after the 1990s are more likely to analyse specific vessel types, for example, Dikos and Marcus (2003) analysed the second-hand ship valuation by using newbuilding prices and charter rates on dry bulk shipping market over the period of 1976 and 2002. They developed the model based on the real options approach to analyse shipping investment decision and applied structural partial equilibrium framework to examine the prices of second-hand vessels through the prices of new vessels and the charter rates. The empirical results show that the hidden asset play value in the prices of second-hand vessels had been empirically proven within the developed model. In line with Dikos and Marcus (2003), the study of Tsolakis et al. (2003) examined the second-hand ship prices for the tanker and dry bulk markets from 1960 to 2001. They analysed the price valuation by Error Correction Model. The model consists of comparatively comprehensive variables, such as the newbuilding price, the interest rates and time charter rate. Their main finding is that second-hand prices in different types of ships react differently to the underlying fundamental factors. They indicate that newbuilding prices have a higher effect on the determination of second-hand prices than time charter rate.

Both Dikos and Marcus (2003) and Tsolakis et al. (2003) applied modern finance theories and advanced econometric methods: Real Option approach and Error Correction Model respectively. Analyzing the different shipping markets through financial theories and advanced econometric models contributed twofold to the literature: first, interpreting the industry with modern financial tools provided an insight to understand the second-hand ship valuation with a financial approach, second, advanced econometric tools eliminated previous statistical drawbacks such as multi-collinearity and heteroscedasticity problems. Moreover, these two paper inspired many future researchers to develop their model based on advanced financial approaches and applying advanced econometric tools.

Furthermore, with the right timing of investment, the return can increase. Especially, in the shipping industry as a highly capital intensive industry, timing is a key concept to increase return and control the risk. Alizadeh and Nomikos (2007) used the price-earnings ratio to investigate investment decision in the sale and purchase market for dry bulk ships over the period of 1976 to 2004. They proposed a co-integration approach for timing investment and divestment decisions in shipping markets. The proposed model, second-hand ship price-earnings (P/E) ratio, was developed as a substitute approach to the usage of Efficient Market Hypothesis in the shipping industry. Their findings supported that the relationship between second-hand ship price and earnings may guide about the future behaviour of ship price, which can be used for investment timing in shipping markets. Furthermore, this study has a guidance role to advice market participant with an alternative investment decision tool; the price-earnings ratio that reflects the relative degree of over or undervaluation in asset prices. Gkochari (2015) had also recently studied the investment timing in dry bulk shipping market by applying the combined methods of option pricing (Real Option Analysis) and game theory, called the combination as option games approach which has been initially introduced in this paper. The extended model can be accepted as an adaption of Real Option Analysis (Dixit and Pindyck 1994) into dry bulk shipping market. The extended model contributed to the understanding of boom-and-bust cycles in shipping industry which is mainly caused by construction cascades, and recession-induced construction booms are the time-to-build delay. Lastly, the author used the $\log \mathrm{P} / \mathrm{E}$ ratio to test its role 
in informing investors for future of the market. She found that the $\log \mathrm{P} / \mathrm{E}$ holds guiding characteristic during market fluctuations and the movement of this ratio can be accepted as a signal for the new investment decision.

Kalouptsidi (2014) had a study to explore the nature of fluctuations of demand for sea transport and the effect of time to build on the level and volatility of the investment. She applied extensive theoretical and econometric tools used to explain the fluctuations on demand for bulk transport and time to build effect on investment through second-hand ship sale transactions, shipping voyage contracts, newbuilding transactions and demolitions from 1998 to 2010. The model proposed in this study lied within the general class of dynamic games in Ericson and Pakes (1995) and is closest to the model of entry and exit in Pakes et al. (2007). Their findings showed that the investment volatility is significantly higher as the time to build declines; on the other hand, prices are less volatile as the time to build declines. In line with Alizadeh and Nomikos (2007) and Kalouptsidi (2014), Greenwood and Hanson (2015) studied the investment cyclicality of the shipping industry considering the investment boom and bust cycles, and returns on capital in the dry bulk shipping industry. They proposed and estimated a behavioural model of industry cycles. In the model, firms over extrapolate exogenous demand shocks and partially neglect the endogenous investment response of their competitors. They found that firms overinvest during booms and are disappointed by the subsequent low returns.

Dai et al. (2015) analysed volatility spillover effects across the newbuilding and second-hand vessel markets and freight market of dry bulk shipping by applying a tri-variate GARCH model over the period of 2001 and 2012. Although the study is not directly considering ship investments, it has developed a robust argument on newbuilding and second-hand ship price fluctuations and their relationship with freight rate. Therefore, the study has some distinctive contribution to the literature, since it has mainly examined the relationship among the freight rate volatility, newbuilding and second-hand vessel price volatility which has been widely ignored in the mainstream of research. Their results provided some valuable contributions regarding second-hand, newbuilding and freight markets. First, they found the volatility spillover effect from second-hand market to freight market is dominant and, the direction of the volatility is from the newbuilding to the second-hand market gets stronger. Second, they found unidirectional transmission effect between freight market and newbuilding market as volatility transferred from freight market to newbuilding market, but not vice versa. Their findings are partially against the conventional assumption in the shipping industry which is believed that the demand drives the supply. Some critiques can be made about the empirical analysis that runs between 2001 and 2012. During the given time frame, the bulk shipping industry had peak level in vessel prices both in newbuilding and second-hand market and had peak level in freight rates; and right after 2008 Global Financial Crisis (GFC), had a very sharp decrease in all the markets and the economy (Celik Girgin et al. 2017). This might have led to have empirical outputs against conventional approach in the shipping industry since GFC had distorted the market and the freight rate could not reflect the real demand status, or even, in turn, the freight rate volatility could be determined by the instant second-hand vessel transaction price volatility.

Moreover, Dai, Hu and Zhang (Dai et al. 2015) examined additional model to advise ship owners for the time-varying vessel prices. The model introduced the investment ratio, which is a function of conditional variances to covariances of newbuilding and second-hand price volatilities for each period. Therefore, the ship owners and investors can optimise their portfolio management regarding the time-varying vessel prices.

More recently, Papapostolou et al. (2017) investigated the effect of intentional and unintentional herd behaviour in the dry bulk market in the process of newbuilding investment decision and scrapping existing fleet. The herd behaviour among bulk ship-owners was examined by the cross-sectional absolute deviation (CSAD), through asset-return and vessel price valuation methods widely applied by scholars; such as price-earnings (PE) ratio (Alizadeh and Nomikos 2007) and second-handnewbuilding price (SHNB) ratio (Merikas et al. 2008). They detected unintentional herding behaviour while deciding to have newbuilding and scrapping existing vessel. 


\subsubsection{Tanker Shipping Market}

An early example of research into tanker market goes back to Zannetos (1966). He analysed the tanker transport and provided the fundamentals of the economics of tanker transport for the future researchers. He had a significant contribution to the literature regarding the competitive markets and ownership patterns, economies of scale, the relationship between freight rates and oil prices, capital mobility, and elastic expectations. The study is still useful with a theoretical approach, although its empirical part became obsolete (Veenstra and Fosse 2006).

After the 1990s, the tanker market has been examined by most advanced econometric techniques. Kavussanos (1996) analysed the second-hand tanker market with price volatility and time-varying risk. Time-varying price fluctuations for three main ship sizes are examined by extended ARCH model. The paper influenced by Markowitz (1952)'s Modern Portfolio Selection Theory, described the portfolio selection process by the ship-owners as profit-maximising agents which have a portfolio of shipping assets, the risk is defined by the return which will be obtained through a different type of assets. The findings are empirically explained the high market fluctuations during and right after periods of significant imbalances, such as the oil crisis in 1980 and Iran-Iraq War in 1979. Also, the paper explicitly showed the role of oil prices in price changes and eventually, it affects the behaviour of investors in the industry. Specifically, it indicated that oil prices and second-hand tanker prices changes have a negative relationship and at the same time, oil prices and volatilities of tanker price changes have a positive relationship. Three types of vessel are highly exposed to external shocks with the larger vessels being more risk-prone. Therefore the price of larger vessels is more volatile than smaller ones for the given period (1980-1993). The research directly advices the investors by stating riskier vessel for the given time frame and defined sample.

More recently, Alizadeh and Nomikos (2006) analysed buy and sell trading strategies for the tanker vessel based on their size. This study is preliminary work of Alizadeh and Nomikos (2007). In both studies, the earnings-price ratio was used to investigate investment decision in the sale and purchase market. Their findings indicated that the relationship between price and earnings in shipping markets contains essential information about the future behaviour of ship prices. The volatility in prices of larger tankers is higher than in smaller ones which provides an excellent opportunity for asset players.

Merikas, Merika and Koutroubousis (Merikas et al. 2008) had seminal study in tanker carrier; they introduced a variable of the ratio of second-hand price over the newbuilding price $(\mathrm{SH} / \mathrm{NB})$ as a useful decision-making tool in the tanker market. They used SH/NP ratio as a dependent variable to analyse the relationship between the main shipping markets and to compare this relationship within the different type of vessels in the tanker industry. They analysed the cointegration relationship between the ratio of SH/NP with freight rate, international trade, shipbuilding cost, market risk (freight rate volatility), crude oil price, and interest rate through the Error Correction Model. They found that in a booming freight market, a ship-owner needs to purchase a modern second-hand vessel to capitalise on the strong freight market. When the freight market drops, the ship-owner should order new vessels, due to the optimism regarding the recovery of the market in the future.

\subsection{Container Shipping Market}

The consequence of the booming process of containerization over the period of 1970-80s (Broeze 2002), the investment in container shipping has considerably increased. The order book for container ships increased from 11.922 to 43.259 thousand dwt from 2000 to 2016 (UNCTAD 2016). Along with the increase in investment, container shipping market has recently received increasing attention from scholars. The study of Luo, Fan and Liu (Luo et al. 2009) analysed the container freight rate fluctuation attributable to the interactions of demand for container transportation services and the container fleet capacity. They empirically evaluated demand increase and fleet capacity increase which will lead to freight rate increase. Besides, the authors focused on the future freight rates after the 2008 Global Financial Crisis (GFC). They generated a forecasting model where freight rates fluctuate due to 
the impact of decreasing demand in the international trade. The freight rate is expected to decrease as demand decreased sharply after the crisis. In the post GFC period of, newbuilding orders were cancelled, which leads a supply to decrease. They predicted the future response of the freight market as a circular movement whereby after the cancellation of newbuilding orders freight rate decrease is restrained by a certain amount. The expectation is that by the cyclical effect the freight rate will slowly increase.

The ship capacity expansion and ship choice decision in containers have been studied by Fan and Luo (2013). They extensively outlined the container market and provided a binary choice model to examine the capacity expansion decisions and nested logit models to examine ship selection decisions. They found that investors are keen to invest when demand and charter rates are high. They provided some valuable insight into investment behaviour of the companies listed in top 20, where they invest to keep their market share at a stable level, while the rest invest aggressively in obtaining high growth. Furthermore, they found that ship companies initially decide whether to order a new ship or a second-hand ship instead of deciding ship size. Based on their empirical findings, new vessels are more favourable than second-hand ships in the container market, when time to build is short, and demand is low. When building time is long, and market demand is high, then second-hand ships become more favourable. Moreover, the dynamic relationship between newbuilding prices, time charter rates and second-hand ship prices in the container market has been investigated by Fan and Yin (2015). They applied two different analysis methods to investigate the dynamic correlations among newbuilding prices, second-hand prices and freight rates in the container market; VAR cointegration model to test the long run correlation among the three variables and Bai-Perron test to analyse multiple structural changes in multiple linear models. Their results confirmed the existence of structural changes in the correlation between ship prices and freight rates. The authors also found that while freight rate is decreasing, the newbuilding price is more fluctuating than the time charter rate and the second-hand price. However, while freight rate is increasing, the time charter rate is more fluctuating; and in a matured stable situation, the second-hand prices get in increasing trend.

After reviewing the empirical papers on investments in maritime transport based on their vessel types, Table 1 Literature Review Summary will provide a brief summary of the selected papers. 
Table 1. Literature Review Summary.

\begin{tabular}{|c|c|c|c|c|c|c|}
\hline & Scope and Approach & Dataset/Sample & Dependent Var. (Output) & Independent Var. (Input) & Key Findings & Study/Authors \\
\hline 1 & $\begin{array}{l}\text { Second-hand ship prices } \\
\text { valuation analysis/Real Option } \\
\text { Value Approach }\end{array}$ & $\begin{array}{l}\text { Tanker and Dry } \\
\text { Bulk/Entire world }\end{array}$ & Second-hand price of a vessel & $\begin{array}{l}\text { New Vessel Expenses } \\
\text { The ratio of time charter earnings } \\
\text { and capital expenses } \\
\text { (EBITDA/CAPEX) } \\
\text { Time charter rate } \\
\text { Depreciation }\end{array}$ & $\begin{array}{l}\text { They provided substantial evidence for a } \\
\text { time-varying market price of risk. In } \\
\text { other words, the hidden asset play value } \\
\text { in the prices of second-hand vessels has } \\
\text { been empirically proven within the } \\
\text { developed model. }\end{array}$ & Dikos and Marcus (2003) \\
\hline 2 & $\begin{array}{l}\text { Econometric analysis of } \\
\text { second-hand ship prices/Error } \\
\text { Correction Model }\end{array}$ & $\begin{array}{l}\text { Tanker and Dry } \\
\text { Bulk/Entire world }\end{array}$ & Second-hand price of a vessel & $\begin{array}{l}\text { Time charter rate } \\
\text { New Building Price } \\
\text { Order book/Fleet Ratio } \\
\text { LIBOR (cost of capital) }\end{array}$ & $\begin{array}{l}\text { New building and time charter have a } \\
\text { significant effect on all determinants of } \\
\text { second-hand prices. The cost of capital } \\
\text { was found insignificant in tanker, in bulk, } \\
\text { it is significant and negative in long run }\end{array}$ & Tsolakis et al. (2003) \\
\hline 3 & $\begin{array}{l}\text { Analysing the role incentives on } \\
\text { investment levels/Capacity } \\
\text { Utilization Approach }\end{array}$ & UK Shipping Industry & Investment & $\begin{array}{l}\text { Capacity utilisation } \\
\text { Existing capital stock } \\
\text { Change in output } \\
\text { Investment incentives } \\
\text { Credit arrangements } \\
\text { Expectations (New orders) }\end{array}$ & $\begin{array}{l}\text { Despite the expectation of the positive } \\
\text { link between investments and } \\
\text { government incentives, the output } \\
\text { showed that there is a } \\
\text { negative relationship. }\end{array}$ & Marlow (1991c) \\
\hline 4 & $\begin{array}{l}\text { Analysing the investment and } \\
\text { divestment decisions/The } \\
\text { Stationary Bootstrap Approach }\end{array}$ & Dry Bulk/Entire world & Investment/Divestment & $\begin{array}{l}\text { Five years old Ship Prices } \\
\text { Time charter rates } \\
\text { Price/Earnings }\end{array}$ & $\begin{array}{l}\text { Strategies based on earnings-price ratios } \\
\text { out-perform buy and hold strategies in } \\
\text { the second-hand market for ships. This is } \\
\text { especially true in the market for larger } \\
\text { vessels because of higher volatility in the } \\
\text { larger size sections }\end{array}$ & Alizadeh and Nomikos (2007) \\
\hline 5 & $\begin{array}{l}\text { Analysing the impact of } \\
\text { time-to-build and demand } \\
\text { uncertainty on investment and } \\
\text { prices/Dynamic Games Model }\end{array}$ & Dry Bulk/Entire World & Investment & $\begin{array}{l}\text { Second-hand ship prices } \\
\text { Scrap Value } \\
\text { Profits } \\
\text { Shipbuilding Prices }\end{array}$ & $\begin{array}{l}\text { Their findings showed that the } \\
\text { investment volatility is significantly } \\
\text { higher as building time declines. Also, } \\
\text { prices are less volatile as time to } \\
\text { build declines }\end{array}$ & Kalouptsidi (2014) \\
\hline 6 & $\begin{array}{l}\text { Analysing the nexus between } \\
\text { freight rate, newbuilding, } \\
\text { second-hand vessel price/The } \\
\text { Tri-variate GARCH model }\end{array}$ & Dry Bulk/Entire world & \begin{tabular}{lc}
\multicolumn{2}{l}{ The conditional covariances between: } \\
$-\quad$ Freight rate-newbuilding market \\
$-\quad$ & Freight rate-second-hand market \\
- & Newbuilding-second-hand market
\end{tabular} & $\begin{array}{ll}\text { Volatility of } \\
-\quad \text { Freight rate } \\
-\quad \text { Newbuilding price } \\
-\quad \text { Second-hand price }\end{array}$ & $\begin{array}{l}\text { Their results prove the existence of } \\
\text { significant bilateral and unidirectional } \\
\text { interactions among the freight rate } \\
\text { market, Newbuilding vessel and } \\
\text { second-hand vessel market. }\end{array}$ & Dai et al. (2015) \\
\hline 7 & $\begin{array}{l}\text { The relationship between } \\
\text { investment boom and bust cycles } \\
\text { and returns on capital/Asset } \\
\text { Pricing Approach }\end{array}$ & Dry Bulk/Entire world & Excess return & $\begin{array}{l}\text { Real Earnings } \\
\text { Real Price } \\
\text { Investment }\end{array}$ & $\begin{array}{l}\text { The firms overinvest during booms and } \\
\text { are disappointed by the subsequent } \\
\text { low returns. }\end{array}$ & Greenwood and Hanson (2015) \\
\hline 8 & $\begin{array}{l}\text { Analysing the time-varying risk } \\
\text { and price fluctuations for the } \\
\text { second-hand } \\
\text { ships/ARIMA-ARCH model }\end{array}$ & Tanker/Entire world & $\begin{array}{l}\text { Second-hand ship prices (Aframax, } \\
\text { Suezmax, VLCC) }\end{array}$ & $\begin{array}{l}\text { Oil prices } \\
\text { Freight rates } \\
\text { Interest Rates } \\
\text { Freight Market Balance Variable }\end{array}$ & $\begin{array}{l}\text { Oil prices and second-hand ship prices } \\
\text { negatively correlated, while oil prices } \\
\text { and price volatilities positively correlated. } \\
\text { Large vessels are riskier than smaller } \\
\text { vessels in the tanker market. }\end{array}$ & Kavussanos (1996) \\
\hline
\end{tabular}


Table 1. Cont.

\begin{tabular}{|c|c|c|c|c|c|c|}
\hline & Scope and Approach & Dataset/Sample & Dependent Var. (Output) & Independent Var. (Input) & Key Findings & Study/Authors \\
\hline 9 & $\begin{array}{l}\text { Analysing the investment timing } \\
\text { and divestment decisions/The } \\
\text { Stationary Bootstrap Approach }\end{array}$ & Tanker/Entire world & $\begin{array}{l}\text { Investment/Divestment (Handysize, } \\
\text { Suezmax, VLCC) }\end{array}$ & $\begin{array}{l}\text { Five-year old Ship Prices } \\
\text { Time charter rates } \\
\text { Price/Earnings }\end{array}$ & $\begin{array}{l}\text { The relationship between price and } \\
\text { earnings in shipping markets contains } \\
\text { important information about the future } \\
\text { behavior of ship prices. } \\
\text { The volatility in prices of larger vessel is } \\
\text { higher than in smaller ones. }\end{array}$ & Alizadeh and Nomikos (2006) \\
\hline 10 & $\begin{array}{l}\text { Investment decision modelling } \\
\text { new building vs } \\
\text { second-hand/Error correction } \\
\text { model }\end{array}$ & Tanker/Entire world & Second-hand Price/New Building Price & $\begin{array}{l}\text { Avg. time charter rate } \\
\text { Sale and buy market transactions } \\
\text { Cost per gross tonnage } \\
\text { Freight rate volatility } \\
\text { Price of crude oil } \\
\text { LIBOR }\end{array}$ & $\begin{array}{l}\text { In a booming freight market, a } \\
\text { ship-owner needs to buy a second-hand } \\
\text { vessel, as it can be capitalised in the } \\
\text { strong freight market. When the freight } \\
\text { drops, the ship-owner should order new } \\
\text { vessels, due to the optimism regarding } \\
\text { the recovery of the market in the future. }\end{array}$ & Merikas et al. (2008) \\
\hline 11 & $\begin{array}{l}\text { Analysis of newbuilding prices, } \\
\text { time charter rates and } \\
\text { second-hand ship } \\
\text { prices/Johansen's VAR }\end{array}$ & Container/Entire world & New building price index & $\begin{array}{l}\text { Containership Time charter Rate } \\
\text { Index } \\
\text { Second-hand Prices Index }\end{array}$ & $\begin{array}{l}\text { In a decreasing market, the newbuilding } \\
\text { price is more active than the time charter } \\
\text { rate and the second-hand price. In an } \\
\text { increasing market instead, the time } \\
\text { charter rate is more active }\end{array}$ & Fan and Yin (2015) \\
\hline 12 & $\begin{array}{l}\text { Capacity expansion and ship } \\
\text { choice decisions analysis / Binary } \\
\text { choice and nested logit models }\end{array}$ & $\begin{array}{l}153 \text { Shipping } \\
\text { Companies/Container } \\
\text { Market }\end{array}$ & $\begin{array}{l}\text { Capacity expansion decision } \\
\text { Ship investment (NB-SH) and vessel type } \\
\text { decision }\end{array}$ & $\begin{array}{l}\text { Fixed cost per ship } \\
\text { Capital cost } \\
\text { Total market demand } \\
\text { Avg. size of the vessel } \\
\text { Size of the company } \\
\text { Freight rates } \\
\text { Container throughput } \\
\text { The ratio of chartered capacity to } \\
\text { total capacity } \\
\text { Total capacity of company } \\
\text { Company's market share } \\
\text { The average vessel size } \\
\text { Freight rates } \\
\text { Newbuilding price } \\
\text { Second-hand price } \\
\text { The unit investment cost } \\
\text { Ship construction lag }\end{array}$ & $\begin{array}{l}\text { Most expansion decisions are } \\
\text { market-driven, and large companies } \\
\text { expand to maintain their market shares } \\
\text { They found that ship companies decide } \\
\text { first new order or second-hand before } \\
\text { ship size. } \\
\text { Also, new orders are preferable to } \\
\text { second-hand. } \\
\text { The substitution of new orders and } \\
\text { second-hand purchases is possible, but } \\
\text { not symmetrical }\end{array}$ & Fan and Luo (2013) \\
\hline 13 & $\begin{array}{l}\text { Freight rate relations with ship } \\
\text { building decision/3SL method }\end{array}$ & Container/Entire world & Container throughput & $\begin{array}{l}\text { Freight rate } \\
\text { Fleet capacity } \\
\text { Bunker price } \\
\text { Delivery } \\
\text { Scrap } \\
\text { New Order }\end{array}$ & $\begin{array}{l}\text { They analysed freight rate cyclical effect } \\
\text { under the demand and supply effect. } \\
\text { Also, they had some prediction about } \\
\text { future freight rate after Global Financial } \\
\text { Crisis, 2008. }\end{array}$ & Luo et al. (2009) \\
\hline
\end{tabular}




\section{Conclusions and Future Works}

The paper elaborated two distinctive subjects: the theoretical review of the firm-level investment theories and ship investment literature. The first part was undertaken to provide the theoretical review of the firm-level investment theories along with their main features and critiques. The second part was constructed to assess the literature on ship investments, in particular, to reveal existing literature in the context of newbuilding, second-hand and freight market relationships by two main vessel types, Bulk and Container Shipping.

The firm-level investment theories have shown continuous advancement to identify the maximum level of firm value by dissolving the drawbacks of the previous investment models over the period of the 1900s to 1970s. Indeed, five mainstream theories; accelerator, expected profit, liquidity, neoclassical and $Q$ theory, provided that most of the investment theories deal with determinants of investments by assuming either instantaneous adjustment or distributed lag structure which is not related to any optimisation process. The latest and advanced $Q$ theory is the only exception which contains theoretical foundations to allow a study of investment determinants in accordance with economic relationship. This allows gathering more plausible output by capturing broader information on investment and economic relationship.

The firm-level investments in fixed capital are central to the understanding of economic activities. The considerable fluctuation in investment expenditures can lead to aggregate fluctuations in the industry and the economy. Insufficient firm level investments closely link to reduced long-run industrial growth, and this might lead to waste of sources and oversupply problems in the short term. The firm-level investment decision is thus a crucial topic on steady industrial growth along with economic growth. To interpret the firm level investment decision within empirical approach by applying investment theories to either firm-level studies or industry level studies is crucial in the context of maximizing the firm/industry value by reaching optimum level and asset price valuation link. In the literature, firm-level investment theories recently and previously applied to various industries; such as manufacturing, finance, banking, housing and airline; and most of the studies proved that the explanatory power of investment theories could not be ignored.

In the shipping industry, the application of firm-level investment theories is not widely adopted. The studies in the ship investment literature mostly analysed the relationship among the shipping markets (newbuilding, second-hand, freight rate and scrap) and their individual/multiple impacts on asset price valuation, the timing of investments and market entry and exit conditions. Although the industry is highly capital intensive and attracts a high amount of investment, insufficient research has been undertaken focusing on maximising the firm/industry value by reaching optimum level and asset price valuation. The existing firm-level investment theories require adaptation to explain the investment decision by ship owners. Particularly given the structure of the bulk and container sectors, the decision might be driven more by expectations of future market conditions rather than asset prices and financial market conditions. This is supported by the existing studies that mostly focus on asset prices and the ratio of new and second-hand ships which is an indication of future expectations, rather than an evaluation of firm's value.

In the context of existing literature in ship investments, further research should be undertaken to investigate the decision making process on ship investments through firm-level investment theories to examine the industry with the microeconomic approach. Utilising investment theories might produce comprehensive findings to define firm-level value maximisation within the approach of the robust investment theories. Therefore, each firm might take advantage of defining the maximum level of firm value to manage investment funds in the long run.

The extensive theoretical foundation of firm-level investment theories and the literature of ship investments, the application of $Q$ model in shipping industry might be more feasible. The $Q$ variable for shipping industry might be defined as the ratio of existing ship prices to the construction costs of new building stand for the ratio of the firm's market value to its replacement cost. 
Author Contributions: S.C.G., T.K. and H.-O.N. conceived and S.C.G. wrote the paper; TK and H.-O.N. contributed to the literature review; S.C.G and TK revised and edited the paper.

Conflicts of Interest: The authors declare no conflict of interest.

\section{References}

Alizadeh, Amir, and Nikos Nomikos. 2006. Trading Strategies in the Market for Tankers. Maritime Policy E Management 33: $119-40$.

Alizadeh, Amir, and Nikos Nomikos. 2007. Investment Timing and Trading Strategies in the Sale and Purchase Market for Ships. Transportation Research Part B: Methodological 41: 126-43. [CrossRef]

Anderson, William Henry Locke. 1964. Corporate Finance and Fixed Investment: An Econometric Study. Boston: Division of Research, Graduate School of Business Administration, Harvard University.

Arrow, Kenneth J. 1962. The Economic Implications of Learning by Doing. The Review of Economic Studies 29: 155-73. [CrossRef]

Baddeley, Catherine. 2002. Investment in an Uncertain World. Zagreb International Review of Economics and Business 5: 1-21.

Balliauw, Matteo. 2017. An Analysis of Entry and Exit Decisions in Shipping Markets under Uncertainty. International Journal of Shipping and Transport Logistics 9: 527-39. [CrossRef]

Barro, Robert J., and Xavier Sala-i Martin. 2004. Economic Growth, 2nd ed.London: The IMT Press.

Bendall, Helen B, and Alan F Stent. 2005. Ship Investment under Uncertainty: Valuing a Real Option on the Maximum of Several Strategies. Maritime Economics E Logistics 7: 19-35.

Bendall, Helen B., and Alan F. Stent. 2007. Maritime Investment Strategies with a Portfolio of Real Options. Maritime Policy \& Management 34: 441-52.

Bolton, Patrick, Hui Chen, and Neng Wang. 2011. A Unified Theory of Tobin's Q, Corporate Investment, Financing, and Risk Management. The Journal of Finance 66: 1545-78. [CrossRef]

Bond, Stephen, and John Van Reenen. 2007. Microeconometric Models of Investment and Employment. In Handbook of Econometrics. Amsterdam: Elsevier, vol. 6, pp. 4417-98.

Brainard, William, and James Tobin. 1968. Pitfalls in Financial Model Building. The American Economic Review 58: 99-122.

Broeze, Frank. 2002. The Globalisation of the Oceans: Containerisation from the 1950s to the Present. St. John's: International Maritime Economic History Association.

Buckley, James J. 2008. The Business of Shipping. Baltimore: Cornell Maritime Press.

Caballero, Ricardo, Eduardo Engel, John Haltiwanger, Michael Woodford, and Robert Hall. 1995. Plant-Level Adjustment and Aggregate Investment Dynamics. Brookings Papers on Economic Activity 2: 1-54. [CrossRef]

Celik Girgin, Sinem, Hong-Oanh Nguyen, and Thanasis Karlis. 2017. Revisiting the Effect of Financial Development on Economic Growth after 2008 Global Financial Crisis. Advances in Economics and Business 5: 456-65. [CrossRef]

Chang, Ha-Joon. 2014. Economics: The User's Guide. London: Penguin Group.

Chenery, Hollis. 1952. Overcapacity and the Acceleration Principle. Econometrica: Journal of the Econometric Society 20: 1-28. [CrossRef]

Cheng, Philip C. 1979. Financial Management in the Shipping Industry. Baltimore: Cornell Maritime Pr/Tidewater Pub.

Chirinko, Robert S. 1993. Business Fixed Investment Spending: Modeling Strategies, Empirical Results, and Policy Implications. Journal of Economic Literature 31: 1875-911.

Clark, John. 1917. Business Acceleration and the Law of Demand: A Technical Factor in Economic Cycles. Journal of Political Economy 25: 217-35. [CrossRef]

Dai, Lei, Hao Hu, and Di Zhang. 2015. An Empirical Analysis of Freight Rate and Vessel Price Volatility Transmission in Global Dry Bulk Shipping Market. Journal of Traffic and Transportation Engineering (English Edition) 2: 353-61. [CrossRef]

Dikos, George. 2008. Real Options Econometrics for Aggregate Tanker Investment Decisions. International Journal of Ocean Systems Management 1: 31-44. [CrossRef]

Dikos, George, and Henry Marcus. 2003. The Term Structure of Second-Hand Prices: A Structural Partial Equilibrium Model. Maritime Economics E Logistics 5: 251-67.

Dixit, Avinash K, and Robert S Pindyck. 1994. Investment under Uncertainty. Princeton: Princeton University Press. 
Duesenberry, James. 1958. Business Cycles and Economic Growth. New York: McGraw-Hill Book Company.

Eisner, Robert, and Robert Strotz. 1963. Commission on Money and Credit, Impacts of Monetary Policy. In Determinants of Business Investment. Englewood Cliffs: Prentice-Hall.

Eklund, Johan E. 2010. Q-Theory of Investment and Earnings Retentions-Evidence from Scandinavia. Empirical Economics 39: 793-813. [CrossRef]

Ericson, Richard, and Ariel Pakes. 1995. Markov-Perfect Industry Dynamics: A Framework for Empirical Work. The Review of Economic Studies 62: 53-82. [CrossRef]

Fan, Lixian, and Meifeng Luo. 2013. Analyzing Ship Investment Behaviour in Liner Shipping. Maritime Policy E Management 40: 511-33.

Fan, Lixian, and Jingbo Yin. 2015. Analysis of Structural Changes in Container Shipping. Maritime Economics $\mathcal{E}$ Logistics 18: 174-91.

Fisher, Irving. 1930. The Theory of Interest Rates. New York: The Macmillan Company.

Gkochari, Christiana C. 2015. Optimal Investment Timing in the Dry Bulk Shipping Sector. Transportation Research Part E: Logistics and Transportation Review 79: 102-9. [CrossRef]

Glen, David, and Steve Christy. 2010. The Tanker Market: Current Structure and Economic Analysis. In Handbook of Maritime Economics and Business. Edited by Costas Grammenos. London: LLP.

Goodwin, Richard. 1948. Secular and Cyclical Aspects of the Multiplier and the Accelerator. In Income, Employment and Public Policy. New York: W.W. Norton \& Co.

Gould, John. 1968. Adjustment Costs in the Theory of Investment of the Firm. The Review of Economic Studies 35: 47-55. [CrossRef]

Greenwood, Robin, and Samuel G Hanson. 2015. Waves in Ship Prices and Investment. The Quarterly Journal of Economics 130: 55-109. [CrossRef]

Grunfeld, Yehuda. 1960. The Determinants of Corporate Investment. In The Demand for Durable Goods. Edited by A.C. Harberger. Chicago: University of Chicago Press, pp. 211-66.

Hall, Robert. 2001. The Stock Market and Capital Accumulation. American Economic Review 91: 1185-202. [CrossRef]

Harlaftis, Gelina, and George Kostelenos. 2012. International Shipping and National Economic Growth: Shipping Earnings and the Greek Economy in the Nineteenth Century. The Economic History Review 65: 1403-27. [CrossRef]

Harlaftis, Gelina, Stig Tenold, and Jesús M. Valdaliso. 2012. Epilogue: A Key Industry or an Invisible Industry? In The World's Key Industry History and Economics of World Shipping. Edited by Gelina Harlaftis, Stig Tenold and Jesus Valdaliso. London: Palgrave Macmillan, pp. 263-72.

Hayashi, Fumio. 1982. Tobin's Marginal Q and Average Q: A Neoclassical Interpretation. Econometrica: Journal of the Econometric Society 50: 213-24. [CrossRef]

IMF. 2017. World Economic Outlook. Washington: International Monetary Fund.

Jorgenson, Dale. 1963. Capital Theory and Investment Behavior. The American Economic Review 53: 247-59.

Jorgenson, Dale. 1967. The Theory of Investment Behavior. In Determinants of Investment Behavior. Edited by Robert Ferber. New York: NBER.

Jorgenson, Dale. 1971. Econometric Studies of Investment Behavior: A Survey. Journal of Economic Literature 9: 1111-47.

Jorgenson, Dale, and Calvin Siebert. 1968. A Comparison of Alternative Theories of Corporate Investment Behavior. The American Economic Review 58: 681-712.

Kalecki, Michael. 1949. A New Approach to the Problem of Business Cycles. The Review of Economic Studies 16: 57-64. [CrossRef]

Kalouptsidi, Myrto. 2014. Time to Build and Fluctuations in Bulk Shipping. The American Economic Review 104: 564-608. [CrossRef]

Kang, J. Y., Song Kim, Hugh Murphy, and Stig Tenold. 2016. British Financial, Managerial and Technical Assistance in Establishing the Global Shipbuilding Giant, Hyundai Heavy Industries. International Journal of Maritime History 28: 81-101. [CrossRef]

Karakitsos, Elias, and Lambros Varnavides. 2014. Maritime Economics: A Macroeconomic Approach. London: Palgrave Macmillan.

Kavussanos, Manolis. 1996. Price Risk Modelling of Different Size Vessels in the Tanker Industry Using Autoregressive Conditional Heterskedastic (Arch) Models. Logistics and Transportation Review 32: 161-76. 
Keynes, John Maynard. 1936. The General Theory of Employment, Interest and Money. London: Palgrave Macmillan. Kilponen, Juha, and Fabio Verona. 2016. Testing the Q Theory of Investment in the Frequency Domain. Bank of Finland Research Discussion Paper 32: 1-27.

Klein, Lawrence. 1951. Studies in Investment Behavior. In Conference on Business Cycles. New York: NBER.

Kopcke, Richard. 2001. The Performance of Traditional Macroeconomic Models of Businesses' Investment Spending. New England Economic Review 2: 1-39.

Koyck, Leendert Marinus. 1954. Distributed Lags and Investment Analysis. Amsterdam: North-Holland Publishing Company.

Kuh, Edwin. 1963. Capital Stock Growth: A Micro-Econometric Approach. Amsterdam: North Holland Publishing Company.

Li, Michael ZF, Tae H Oum, and Yimin Zhang. 2004. Tobin's Q and Airline Performances. Public Works Management E Policy 9: 51-65.

Lucas, Robert, Jr. 1967. Adjustment Costs and the Theory of Supply. Journal of Political Economy 75: 321-34. [CrossRef]

Luo, Meifeng, Lixian Fan, and Liming Liu. 2009. An Econometric Analysis for Container Shipping Market. Maritime Policy \& Management 36: 507-23.

Markowitz, Harry. 1952. Portfolio Selection. The journal of Finance 7: 77-91.

Marlow, Peter B. 1991a. Shipping and Investment Incentives: A Trilogy. Maritime Policy E Management 18: 123-38.

Marlow, Peter B. 1991b. Shipping and Investment Incentives: A Trilogy† Part 2. Investment Incentives for Shipping. Maritime Policy \& Management 18: 201-16.

Marlow, Peter B. 1991c. Shipping and Investment Incentives: A Trilogy Part 3. The Effectiveness of Investment Incentives for Shipping — the Uk Experience 1950-1987. Maritime Policy \& Management 18: 283-311.

McCloskey, Deirdre N. 2002. The Secret Sins of Economics. Chicago: Prickly Paradigm.

McCloskey, Deirdre N. 2006. Bourgeois Virtue. Chicago: University of Chicago Press.

Merikas, Andreas, Anna Merika, and George Koutroubousis. 2008. Modelling the Investment Decision of the Entrepreneur in the Tanker Sector: Choosing between a Second-Hand Vessel and a Newly Built One. Maritime Policy \& Management 35: 433-47.

Metaxas, Basil. 1971. The Economics of Tramp Shipping. London: Athlone Press.

Meyer, John, and Robert Glauber. 1964. Investment Decisions, Economic Forecasting, and Public Policy. Boston: Division of Research, Harvard Business School.

Meyer, John, and Edwin Kuh. 1957. The Investment Decision: An Empirical Study. Cambridge: Harvard University Press.

Paine, Lincoln. 2014. The Sea and Civilization: A Maritime History of the World. New York: Vintage Books.

Pakes, Ariel, Michael Ostrovsky, and Steven Berry. 2007. Simple Estimators for the Parameters of Discrete Dynamic Games (with Entry/Exit Examples). The Rand journal of economics 38: 373-99. [CrossRef]

Papapostolou, Nikos, Panos Pouliasis, and Ioannis Kyriakou. 2017. Herd Behavior in the Drybulk Market: An Empirical Analysis of the Decision to Invest in New and Retire Existing Fleet Capacity. Transportation Research Part E: Logistics and Transportation Review 104: 36-51. [CrossRef]

Peters, Ryan, and Lucian Taylor. 2017. Intangible Capital and the Investment-Q Relation. Journal of Financial Economics 123: 251-72. [CrossRef]

Romer, David. 2006. Advanced Macroeconomics. New York: McGraw Hill/Irwin.

Rua, António. 2011. A Wavelet Approach for Factor-Augmented Forecasting. Journal of Forecasting 30: 666-78. [CrossRef]

Skjeggedal, Eli. 2012. The Q Theory Model of Housing: A Macroeconomic Analysis of the Dynamics in the Norwegian Housing Market. Bergen: NORGES HANDELSHØYSKOLE.

Stopford, Martin. 2009. Maritime Economics, 3rd ed. London: Routledge.

Talley, Wayne K. 2011. The Blackwell Companion to Maritime Economics. West Sussex: John Wiley \& Sons.

Tinbergen, Jan. 1938. Statistical Evidence on the Acceleration Principle. Economica 5: 164-76. [CrossRef]

Tinbergen, Jan. 1939. Statistical Testing of Business Cycle Theories: Part I: A Method and Its Application to Investment Activity. New York: Agaton Press.

Tobin, James. 1969. A General Equilibrium Approach to Monetary Theory. Journal of Money, Credit and Banking 1: 15-29. [CrossRef]

Tobin, James. 1978. Monetary Policies and the Economy: The Transmission Mechanism. Southern economic journal 44: 421-31. [CrossRef] 
Tsiang, Sho-Chieh. 1951. Accelerator, Theory of the Firm and the Business Cycle. The Quarterly Journal of Economics 65: 325-41. [CrossRef]

Tsolakis, S., C. Cridland, and Hercules Haralambides. 2003. Econometric Modelling of Second-Hand Ship Prices. Maritime Economics \& Logistics 5: 347-77.

UNCTAD. 2016. Review of Maritime Transport. Geneva: United Nations Conference on Trade and Development. UNCTAD. 2017. Review of Maritime Transport. Geneva: United Nations Conference on Trade and Development. Uzawa, Hirofimi. 1965. Optimal Technical Change in an Aggregative Model of Economic Growth. International Economic Review 6: 18-31. [CrossRef]

Veenstra, Albert W, and Sébastien De La Fosse. 2006. Contributions to Maritime Economics-Zenon S. Zannetos, the Theory of Oil Tankship Rates. Maritime Policy \& Management 33: 61-73.

Zannetos, Zenon S. 1966. The Theory of Oil Tankship Rates. London: Massachusetts Institute of Technology.

(c) 2018 by the authors. Licensee MDPI, Basel, Switzerland. This article is an open access article distributed under the terms and conditions of the Creative Commons Attribution (CC BY) license (http://creativecommons.org/licenses/by/4.0/). 